\title{
The Leadership of Schools in Improving the Quality of Graduates in SMK Kesehatan Pelita Insani Prabumulih
}

\author{
Muhamad Hafis $^{1 *}$, Happy Fitria ${ }^{2}$, Rohana ${ }^{2}$ \\ ${ }^{1}$ SMA Negeri Prabumulih, South of Sumatra, Indonesia \\ ${ }^{2}$ Universitas PGRI Palembang, Indonesia \\ *Corresponding author.Email: muhamadhafis2016@gmail.com
}

\begin{abstract}
The standard of education still needs to be improved. In an age like today, a nation with high quality education would be better able to tackle the multiple problems that occur. Leadership plays a role in enhancing the standard of education. The position of the principal in schools is very important in improving all aspects that will produce the quality of the teaching and learning process and the results of the process, namely in the form of graduates. This study would address the leadership of the Principal in enhancing the standard of graduates. The data collection methods used were interviews, observation and documentation research. The data analysis methodology used is data reduction, data presentation and conclusion drawing. The triangulation of this study is the result of field observations made by researchers at SMK Kesehatan Pelita Insani Prabumulih. The results of the triangulation reflect the inference that the leadership of the Principal plays a key role in enhancing the standard of graduates.
\end{abstract}

Keywords: Principal Leadership, Quality, Graduation Standard

\section{INTRODUCTION}

The advancement of a nation cannot be separated from the contribution of the world of education to that country. In either region, an advanced country must be assisted by a high-quality education system.

People who have the capacity to create mutual ties with the surrounding natural, social and cultural environment and who can acquire further skills in the world of work or higher education. As a demonstration of the government's seriousness in dealing with education, Chapter II, Article 3 of the Law 20 of 2003 on the National Education System, reads as follows "National education aims to develop the potential of students to become human beings who believe and have devotion to God Almighty have a noble character, are healthy, knowledgeable, capable, creative, independent and become democratic and responsible citizens. "

The accomplishment of the priorities of national education cannot be separated from the leadership of the school principal. Principals can enhance the quality of students through leadership strategies. The style of leadership embraced by the Principal would be connected to the results and success of the Principal in guiding and executing the school education process [1] Principals are expected to be able to develop the strategic steps that will be taken in the management of their schools. The planning of these strategic steps includes all current components, including teachers, students, parents, committees and the community.

The Principal must have a vision, a mission, a creative, imaginative and quality-oriented approach. This approach is a concerted effort on the part of the Principles to continually enhance the standard of the service, so that the emphasis is on teachers and other educational workers, so that the educational institutions they lead will function well. As school leaders and managers, the functions and duties of school principals are very strategic in enhancing the quality of graduates in particular and the quality of education in general. The Principal must be able to practice creativity, be able to lead all participants and the school as an educational institution to change their minds, develop their vision and purpose by using the strengths, expertise and abilities of its members [2].

The standard of education is an indicator of the progress of a country's education process. Education is the most significant predictor for the growth of a nation 
[3]. Quality education would have an effect on different aspects of the country's life. For example, economy and technology. Economy and technology are closely linked. Countries with good economic capabilities will, of course, have access to high-quality technology. On the other hand, a nation with economic problems would find it difficult to become a technology-based country. In order to enhance its execution, an assessment of the program needs to be carried out in order to assess the degree to which the program has been successful and to recognize any defects [4].

Idris and Lestari describe the quality of education as the capacity of schools to handle school components operationally and effectively, thus creating added value for those components. Modern schooling carries the fate of accountability for destructive developments in the moral and spiritual domain of humanity [5]. The school will be able to achieve its vision, mission and objectives if all the school components are able to perform their respective roles. The same is true of the position of school principal.

The research carried out is similar to the research carried out by Maryanti et al [6] where the findings of the analysis indicate that the principal as a leader plays an important role in improving the standard of education. The theory works well in the administration. Evidence of the presence of a neat, well-functioning administration of correspondence in general administration, finance, the library and the systematic management of the curriculum. This activity is carried out in partnership as a professional, imaginative and inventive working team.

And also, research conducted by Fitria et al [7] in which the purpose of this study is to provide a summary of the Principal's leadership in improving the performance of honorary teachers at SMP Muhammadiyah Prabumulih. Collecting research data from three main sources, namely direct observation (observation), record analysis, and interviews to obtain key leadership scores and teacher performance scores. The data analysis method used is a descriptive technique of qualitative analysis.

\section{METHODS}

Methodology is a determining factor for the merits of writing scientific papers [8]. Qualitative analysis is the type of research used in this research. Qualitative research methods: ethnography, case studies, phenomenology, grounded theory, narrative/history, literature review (analysis) as well as research method approaches. The systematics provided in this guideline are of a general nature, and researchers should change the systematics that relate to the chosen research process.
This research was performed at the SMK Kesehatan Pelita Insani Prabumulih and took place between September and December 2020. The data collection techniques used in this study were as follows: 1. Primary data sources are extracted from field experiments, i.e. the method of gathering knowledge and evidence directly on the research subject, by: (a) observation, i.e. making direct observations and noticing the SMK Kesehatan teachers in Prabumulih City, (b) interviews, i.e. data collection by keeping direct and verbal questions and answers to the parties relevant to the topic under review. Data collection methods shall be carried out in accordance with the form of data obtained by interview, observation and recording.

\section{RESULTS AND DISCUSSION}

The results showed that the responses generated by the report, both the principal and the professors who were subjects of study, were consistent and had good results and were consistent with the emphasis and research questions.

The Principal has performed well and proportionately in his role and function as EMASLIM (Educator, Boss, Counselor, Supervisor, Leader, Innovator, and Motivator). As Chief Executive Officer of SMK Kesehatan Pelita Insani, Prabumulih controlled and directed all components of the power of the SMK Kesehatan Pelita Insani Prabumulih to move forward in a harmonious manner.

As an educator, the principal's leadership is always an example for fellow teachers: to plan, introduce and review, and to make follow-up changes to the learning process both within and outside the classroom.

Managers must be able to handle anything in school. From being the school's principal, to handling students who will ultimately become graduates of the SMK Kesehatan Pelita Insani Prabumulih, who will carry the good name of the school and develop their personal reputation.

The classroom execution is in line with the preparation and the teacher is able to address the challenges that emerge in the classroom during the learning process. The Principal, as a consultant or someone who has the capacity to offer advice, helps to provide advice and possible solutions to problems. Particularly in the problems of day-to-day school trips. A strong adviser, he's going to lighten the pressure felt by struggling people. The Principal must serve as a good school counselor.

Academic monitoring focuses on the application of learning. The Principal assists the teacher in carrying out his duties in the classroom. The Principal ensures 
that teachers have good and sufficient learning resources at their disposal. The classroom execution is in line with the preparation and the teacher is able to address the challenges that emerge in the classroom during the learning process.

A good leader is a motivator who never fails to inspire his subordinates. A good leader is not a leader who only gives orders, but a leader who explains how work needs to be done in order to produce maximum performance. With the proper functioning of leadership management, it is expected that the institutions they lead will witness the growth and enhancement of the standard of education [9].

As an innovator, the theory means that the principle has an imaginative and creative spirit. The principal is the driving factor in realizing the vision, mission, including goals [10]. The rules, regulations, vision, purpose and priorities designed and used as the basis for the execution of school activities over a certain period of time (short, medium and long term) are instruments that involve the touch of the school principal to make them a source of power and added value for success in education and school quality. Main, very critical role as a motivator. In the past, the new principal may be a teacher who is inspired by the principal to still make progress in life. Likewise, a good career worker may have been a student who has been inspired by the guidance or example provided by the principal. Through the leadership style that a leader will be able to transfer some values [11].

SMK Kesehatan Pelita Insani Prabumulih teachers have a high degree of expertise in their respective fields. In fact, it is important to increase competence, be it technical, personal, educational or social. Improving skills will be the capital of the SMK Kesehatan Pelita Insani Prabumulih in the service of the community, especially in Prabumulih, which hopes for educational institutions that produce skilled workers in the field of health services.

Of the four competencies, the average teacher at SMK Kesehatan Pelita Insani Prabumulih has technical and social advantages. Teachers or teaching staff with a health professional background still need development in the field of education (pedagogy), whereas general subject teachers need to develop their ability to communicate with students who are prepared to enter the world of business and the world of work.

Teachers of non-productive subjects master pedagogy more but are weak in the social sector, whereas teachers with technical backgrounds who teach productive subjects, on the other hand, are weak in the field of pedagogy, but capable of social contact with students. Teacher competence has an effect on results. If teachers have the ability to develop their skills, they will definitely be better able to carry out their professional duties and responsibilities. If teachers have the ability to develop their skills, they will definitely be better able to carry out their professional duties and responsibilities. In other words, growing competence would increase the performance of teachers

Similar to the previous issue, teacher competence will increase teacher performance and, in turn, teachers with good performance will definitely deliver better learning quality. Strong quality of learning can contribute to higher quality graduates.

With a clear understanding of the strategy, $\mathrm{Mr}$. Muhamad Hafis, S.HI., M.H., has been very active in implementing the SMK Pelita Insani Prabumulih Health Principal Strategy Program.

During the interview with the Principal, the researcher found that his enthusiasm for learning was very high in understanding the various policies introduced by the Government, especially in the field of education, such as the Key Strategy Programme. The findings of the observations, interviews and analyses of the documents collected by the researcher have shown that the School's Head Strategy Program has been well implemented at SMK Kesehatan Pelita Insani Prabumulih. The study focuses on 3 (three) things, namely: the learning process, the freedom and engagement of the teacher and the leadership of the principal, and the researcher has found that the learning process has been well implemented. Teachers are granted the freedom to experiment and to carry out innovative learning, and the principal has performed well the role of the Gold Environment.

The results of the teacher interviews showed that the teachers had a sufficient understanding of the concepts, characterization of the implementation of the minimum competency assessment functions and character surveys. Most teachers are ready and willing to serve as implementers and facilitators if later implementation of the minimum competency assessment and character surveys are carried out as a replacement for the standard of graduates, both within the framework of SMK Pelita Insani Prabumulih Health and in the broader scope of Prabumulih City.

The results noted here by the researchers are the infrastructure that still needs to be changed. The multimedia room or computer lab also needs support to increase the number of Everything in One PCs. This finding was supported by the announcement of the Deputy Principal in the field of facilities, Mrs. Ida Fatria, S.Pd., that the budget for the procurement of multimedia instructional resources through normal BOS funds had been introduced. However, they hope 
that the assistance of related parties, in particular the Prabumulih City Education Office, will accelerate the planning process for SMK Kesehatan Pelita Insani Prabumulih to welcome a new era of graduate quality and the introduction of the 2021 implementation of the minimum competency assessment and character surveys.

As policies and initiatives that have only been implemented in 2019-2020, the standard of graduates and the introduction of implementation of the minimum competency assessment, as well as character surveys, awareness and comprehension of these issues, are not equally distributed. In order to address differences in perceptions on this topic, a platform is required to provide information and awareness to each other. The MGMP (subject teacher deliberation) is a strategic place for teachers at SMK Kesehatan Pelita Insani Prabumulih to exchange information and experience, to equalize expectations about the quality of graduates and to carry out implementation of the minimum competency assessment and character surveys.

In carrying out this analysis, the author recognizes that there are many problems that become limitations in this review, including: 1) conditions at the time of the study were already haunted by the climate of the Covid 19 pandemic; 2) limitations arising from the willingness of the writer to comprehend the literature. So that certain observations in the field are absorbed with sufficient literature without theoretical help, and 3 ) other flaws that unintentionally appear to the writers in this report. For this reason, the authors hope that they will criticize the advice and guidance of all parties.

\section{CONCLUSION}

On the basis of the findings of analysis and debate, the following conclusions can be drawn: (1) several techniques adopted by the Principal will boost the quality of graduates. The quality of graduates is part of the quality of education that involves aspects related to systems, inputs, resources and outputs. The standard of graduates is a reflection of the school, which demonstrates if all these factors are present and wellfunctioning; (2) the Principal has a role and expertise that is very significant in enhancing the performance of teachers. The Principal of the SMK Kesehatan Pelita Insani has played a very important role in improving teacher performance by performing the roles of Instructor, Operator, Counselor, Supervisor, Leader, Innovator and Motivator. As a motivator, the measures taken by the Principal have created excitement for all teachers and education workers to enhance their performance in carrying out their duties and responsibilities in order to improve the standard of education at SMK Kesehatan Pelita Insani Prabumulih, and 3) the Principal has a role and expertise that is very significant in enhancing the performance of teachers. The Principal of the SMK Kesehatan Pelita Insani Prabumulih has played a very important role in improving teacher performance by performing the roles of Instructor, Operator, Counselor, Supervisor, Leader, Innovator and Motivator. As a motivator, the measures taken by the Principal have created excitement for all teachers and education workers to enhance their performance in carrying out their duties and responsibilities in order to improve the standard of education at SMK Kesehatan Pelita Insani Prabumulih.

\section{ACKNOWLEDGMENTS}

The author would like to thank Dr. H. Bukman Lian, M.M., M.Si., Chancellor of the PGRI Palembang University, Dr. Syaiful Eddy, M.Sc., Director of the Postgraduate Program at the PGRI Palembang University, Dr. Happy Fitria, M.Pd., Head of Education Management Study Program and all those who have helped morally and materially. May the goodness become multiple good deeds.

\section{REFERENCES}

[1] Astuti, R. W., Fitria, H., \& Rohana, R. (2020). The Influence of Leadership Styles and Work Motivation on Teacher's Performance. Journal of Social Work and Science Education, 1(2), 105114. Retrieved from https://ejournal.karinosseff.org/index.php/jswse/ar ticle/view/33

[2] Andriani, S., Kesumawati, N., \& Kristiawan, M. (2018). The Influence of the Transformational Leadership and Work Motivation on Teachers Performance. International Journal of Scientific \& Technology Research, 7(7).

[3] Asvio, N., Yamin, M., \& Risnita. (2019). Influence of Leadership Style, Emotional Intelligence and Job Satisfaction toward Organizational Commitment (Survey at SMA Muhammadiyah South Sumatera). International Journal of Scientific \& Technology Research 8 (8).

[4] Areli, A. J., Lian, B., \& Kristiawan, M. (2020). An Evaluation of Implementation Industrial Work Practice Programs in Vocational School. International Journal of Progressive Sciences and Technologies (IJPSAT), 20(2), 179-186.

[5] Maseleno, A., Ayshwary, B., Ivanova, T. N., Hashim, W., Nguyen, P. T., Shankar, K., Kristiawan, M., Huda, M. (2019). General 
Theoretical and Philosophical Aspects of Modern Education. Aspectos Teóricos y Filosóficos Generales de la Educación Moderna. Revista San Gregorio 2019, No. 32 Special Issues August.

[6] Maryanti, N., Kristiawan, M., dan Rohana (2019). Siswa SMK Siap Hadapi Revolusi Industri 4.0 (Kajian Praktis SMK di Provinsi Sumatera Selatan) [Vocational School Students Are Ready to Face the Industrial Revolution 4.0 (Vocational Practical Studies in South Sumatra Province)]. Tesis. Palembang: Universitas PGRI.

[7] Fitria, Fitria, H., dan Martha, A. (2020). Manajemen Kepemimpinan Kepala Sekolah dalam Meningkatkan Kinerja Guru Honorer [Principal Management Leadership in Improving Honorary Teacher Performance]. Journal of Innovation in Teaching and Instructional Media, 1 (1): $85-89$.

[8] Muttaqin, K., \& Rahmadoni, J. (2020). Analysis and Design of File Security System AES (Advanced Encryption Standard) Cryptography Based. Journal of Applied Engineering and Technological Science (JAETS), 1(2), 113-123. https://doi.org/10.37385/jaets.v1i2.78

[9] Hendriyadi, Ritonga, A. H., \& Us, K. A. (2020). Management Leadership in Improving the Quality of Graduates of Private Islamic Religious Colleges in Jambi Province. International Journal of Progressive Sciences and Technologies (IJPSAT) Vol. 23 No. 2 November 2020, pp. 42-51 Retrieved from https://ijpsat.ijshtjournals.org/index.php/ijpsat/article/view/2308

[10] Handayani, D. O., Kristiawan, M., \& Destiniar. (2020). Education and Training for Strengthening Principal to Effective Schools. International Journal of Progressive Sciences and Technologies (IJPSAT), 22(1), 321-326.

[11] Ruslan, Lian, B., \& Fitria, H. (2020). The Influence of Principal's Situational Leadership and Teacher's Professionalism on Teacher's Performance. International Journal of Progressive Sciences and Technologies (IJPSAT), 20(1). Retrieved from https://ijpsat.ijshtjournals.org/index.php/ijpsat/article/view/1733. 